University of Nebraska - Lincoln

DigitalCommons@University of Nebraska - Lincoln

$1-2001$

\title{
Pay and Productivity in a Corporatist Economy: Evidence from Austria
}

Scott M. Fuess Jr.

University of Nebraska-Lincoln, SFUESS1@UNL.EDU

Meghan Millea

Mississippi State University, mjm51@msstate.edu

Follow this and additional works at: https://digitalcommons.unl.edu/econfacpub

Part of the Economics Commons

Fuess, Scott M. Jr. and Millea, Meghan, "Pay and Productivity in a Corporatist Economy: Evidence from Austria" (2001). Economics Department Faculty Publications. 40.

https://digitalcommons.unl.edu/econfacpub/40

This Article is brought to you for free and open access by the Economics Department at DigitalCommons@University of Nebraska - Lincoln. It has been accepted for inclusion in Economics Department Faculty Publications by an authorized administrator of DigitalCommons@University of Nebraska - Lincoln. 


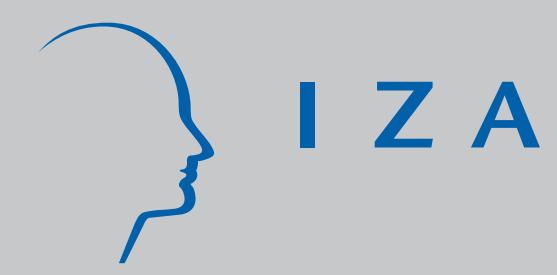

IZA DP No. 244

Pay and Productivity in a Corporatist Economy: Evidence from Austria

Scott M. Fuess, J r.

Meghan Millea

J anuary 2001 


\title{
Pay and Productivity in a Corporatist Economy: Evidence from Austria
}

\author{
Scott M. Fuess, Jr. \\ University of Nebraska and IZA, Bonn \\ Meghan Millea \\ Mississippi State University \\ Discussion Paper No. 244 \\ January 2001 \\ IZA \\ P.O. Box 7240 \\ D-53072 Bonn \\ Germany \\ Tel.: +49-228-3894-0 \\ Fax: +49-228-3894-210 \\ Email: iza@iza.org
}

This Discussion Paper is issued within the framework of IZA's research area The Future of Work. Any opinions expressed here are those of the author(s) and not those of the institute. Research disseminated by IZA may include views on policy, but the institute itself takes no institutional policy positions.

The Institute for the Study of Labor (IZA) in Bonn is a local and virtual international research center and a place of communication between science, politics and business. IZA is an independent, nonprofit limited liability company (Gesellschaft mit beschränkter Haftung) supported by the Deutsche Post AG. The center is associated with the University of Bonn and offers a stimulating research environment through its research networks, research support, and visitors and doctoral programs. IZA engages in (i) original and internationally competitive research in all fields of labor economics, (ii) development of policy concepts, and (iii) dissemination of research results and concepts to the interested public. The current research program deals with (1) mobility and flexibility of labor markets, (2) internationalization of labor markets and European integration, (3) the welfare state and labor markets, (4) labor markets in transition, (5) the future of work, (6) project evaluation and (7) general labor economics.

IZA Discussion Papers often represent preliminary work and are circulated to encourage discussion. Citation of such a paper should account for its provisional character. 
IZA Discussion Paper No. 244

January 2001

\section{ABSTRACT \\ Pay and Productivity in a Corporatist Economy: Evidence from Austria}

Conventional theory predicts that productivity gains lead to hikes in real pay. Efficiency wage theory hypothesizes that pay increases can lead to productivity improvements. But would such results be observed in a corporatist economy with centralized bargaining? For the case of Austria, a corporatist archetype, this study uses an innovative technique developed by Geweke to disentangle the relationship between pay and productivity. There already has been empirical evidence that pay demands in corporatist economies are relatively modest. Moreover, it has been claimed that corporatist coordination enhances the efficiency of labor contracts, by providing a mechanism to adjust to aggregate shocks. Our findings uncover another efficiency benefit of corporatism. For laborers in manufacturing, we find that wage hikes result in productivity gains. Managers, then, are rewarded following improvements in productivity.

JEL Classification: J41, C22, J50, J30

Keywords: Labor Contracts, efficiency wages, corporatism

Scott M. Fuess, Jr.

Department of Economics

University of Nebraska

Lincoln, NE 68588-0489

USA

Tel: +1 402-472-6281

Fax: +1 402-472-9700

Email: sfuess1@unl.edu 


\section{Introduction and Review}

Conventional wage theory predicts that profit-maximizing employers hire labor up to the point where the marginal product of labor equals the real wage. Thus, improvements in productivity will stimulate labor demand and drive up pay. Influence also can work in the other direction. Efficiency wage hypotheses suggest that pay adjustments can improve labor productivity. For example, raising pay can stimulate worker effort and solidify long-term employment relationships (Salop, 1979; Shapiro and Stiglitz, 1984). Akerlof (1982) has proposed that when firms increase pay, employees work harder out of a sense of loyalty to those firms. In a similar vein, Teulings and Hartog (1998, p. 187) have claimed that if wages deviate from norms of fairness, workers retaliate against employers, meaning there will be a link between wage norms and labor productivity.

Productivity should drive pay; likewise pay can influence productivity. But what about in corporatist economy? Corporatism is usually thought of as economy-wide or otherwise institutionalized coordination in the wage-setting process. Such coordination typically involves government, either because legislation extends union contract terms to nonunion workers or because labor negotiations must account for government policies.

Labor settlements in a corporatist economy are affected not so much by market conditions, but institutional and political considerations. Consequently, corporatism may stifle the market mechanism, creating an "institutional sclerosis" (see Flanagan et al., 1983; Olson, 1982). In response, Calmfors and Driffil (1988) have hypothesized that when there is economywide coordination in wage setting, organized labor must take into account the external effects of its demands. Studies have shown that wages in corporatist economies have been responsive to general market conditions, and that such economies have performed better than others in containing inflation and unemployment. ${ }^{1}$

${ }^{1}$ For example, see evidence reported by Bean et al. (1986), Bruno and Sachs (1985), Calmfors and Driffil (1988), Flanagan et al. (1983), Katzenstein (1984), Pichelmann and Wagner (1986), 
Despite comparatively flexible wages, in a corporatist setting it is not clear how pay and productivity will be interrelated. If organized labor does restrain its demands, it may or may not expect wages to react to productivity improvements. Or perhaps settlements to raise pay will actually stimulate productivity gains. With centralized wage setting, is pay responsive to productivity gains? Do wage increases actually contribute to improvements in productivity?

There is no consensus about what exactly constitutes corporatism. Several researchers have formulated indices, attempting to measure corporatism across countries. ${ }^{2}$ Although there are disagreements about these measures, there is consensus that Austria represents the quintessence of a corporatist economy. In every index devised, Austria ranks as the most corporatist country (see Teulings and Hartog, 1998, p. 30). Each year there is centralized bargaining between a national union — representing both "blue-collar" wage earners and "whitecollar" salary earners - and federation of employers. Both sides belong to a Parity Commission for Prices and Wages, which sets national pay policies. Labor pacts do not have to be ratified at a local level and settlement terms extend to nonunion workers.

Considering Austria's corporatist practices, this study investigates the relationship between pay and productivity in that country. In so doing we face a basic identification problem, whether productivity gains are the result or cause of higher pay. ${ }^{3}$ To overcome this problem we utilize a statistical technique developed by Geweke $(1982,1984)$ to assess bi-directional causality between time series, which we use to disentangle pay-productivity relationships in Austria.

Geweke has developed measures of statistical feedback which also account for any interdependence between time series, thereby extending Granger's (1969) definition of causality.

Tarantelli (1986), and Teulings and Hartog (1998).

${ }^{2}$ On measures of corporatism, see Bruno and Sachs (1985), Calmfors and Driffil (1988), and Teulings and Hartog (1998, pp. 26-31).

${ }^{3}$ For discussion of this identification problem, see Campbell (1993), Cappelli and Chauvin (1991), and Carmichael (1990). 
Because this method measures feedback while controlling for any instantaneous association, it can be used to disentangle the direction and magnitude of the linear relationships between two time series. Although known to statisticians, economists only recently have incorporated the method to clarify relationships among variables. ${ }^{4}$

Using Austrian time series for the 1954-1995 period, we apply Geweke's linear feedback technique. This procedure allows us to measure the extent to which (1) productivity has led employee earnings and (2) earnings have led productivity, while separately identifying any simultaneous association between the two series. We use the Geweke feedback measures to verify whether pay adjustments indeed have influenced productivity and vice versa.

Data for Austrian manufacturing distinguish between wage earnings of blue-collar workers and salary earnings of white-collar workers. Therefore, we can assess how wages or salaries are related, if at all, to productivity in the economy.

\section{Setting Pay in Austria}

Before attempting to sort out pay and productivity, it is necessary to consider how pay is set in Austria. This topic has been detailed elsewhere, so we present only a brief summary. ${ }^{5}$

On the labor side, the key party is the Austrian Trade Union Federation (German acronym: ÖGB). The ÖGB monopolizes organized labor in the country, settling labor contracts on behalf of its affiliates. ${ }^{6}$ As noted by Karlhofer and Ladurner (1993), approximately three-

${ }^{4}$ For detailed analysis and discussion of the Geweke method, including economists' adaptations of the method, see Millea (1998).

${ }^{5}$ For example, see Karlhofer and Ladurner (1993), Kindley (1992), Nowotny (1993), and Pichelmann and Wagner (1986).

${ }^{6}$ Thirteen (formerly fifteen) affiliates represent employees in both the private and public sectors, spanning industries and occupations. For example, there are separate affiliates for metal workers, railway workers, private sector salary earners, and so on. Yet the affiliates are only subgroups of the ÖGB. It is the ÖGB itself that coordinates pay claims and settles contracts on behalf of its affiliates. 
fifths of the labor force belongs to the union federation, but virtually all wage and salary earners are subject to collective agreements negotiated by the ÖGB.

Virtually all interest groups in Austria are organized in self-governing bodies called "chambers." There are separate groups for farmers, lawyers, physicians, employers, et cetera. There are also respective Chambers of Labour, organized into the Federal Chamber of Labour (acronym: BAK). ${ }^{7}$ The BAK provides a forum for labor interests to be voiced in public affairs, but the power to negotiate pay settlements resides exclusively with the ÖGB.

On the employer side, numerous chambers represent firms in areas such as commerce, industry, trade, transport, tourism, and finance, credit, and insurance. These employer groups constitute the Federal Economic Chamber (BWK).

In Austria there is a formal "social partnership" between labor, business, and government. This tripartite arrangement has been in place since 1957, when the Parity Commission for Prices and Wages (Paritätische Kommission für Preis- und Lohnfragen) was established. ${ }^{8}$ The commission is the primary pay setting institution in the country. Its mission is to coordinate annual labor contracts with government policies, thereby providing institutional control of wages and prices. Representing labor on the commission are two delegates each from the ÖGB and BAK. On behalf of employers, there are two delegates each from the BWK and the Conference of Chambers of Agriculture. Parity Commission decisions can be implemented only by unanimous vote. ${ }^{9}$ The commission is chaired by Austria's Federal Chancellor and attended by

\footnotetext{
${ }^{7}$ Membership in a Chamber of Labour is compulsory for employees, except public servants and agricultural workers.

${ }^{8}$ In an effort to control spiralling inflation after World War II, a number of centralized priceand-wage accords had been implemented in the late 1940s and early 1950s.

${ }^{9}$ The Parity Commission has a subcommittee on wages, which provides continuing review of the ÖGB's wage management guidelines.
} 
representatives of pertinent government ministries. ${ }^{10}$

In guiding pay settlements, the Parity Commission ostensibly takes into account productivity, solidarity, and the state of the business cycle. Focusing on the years 1968-1984, Pichelmann and Wagner (1986) found that pay growth was directly related to productivity growth. But that study did not attempt to control for feedback, that is, possible influence of pay on productivity. Considering the social solidarity necessary to achieve labor contracts, when pay hikes actually are granted, workers' efforts may be affected. Thus, it is necessary to identify how pay and productivity are interrelated.

\section{The Geweke Linear Feedback Method: Overview}

Suppose there are two time series vectors prd (productivity) and pay (worker pay). Geweke (1982) decomposes linear dependence between the series into three components: (1) feedback from prd to pay, (2) feedback from pay to $p r d$, and (3) contemporaneous (simultaneous) association between the series. Whereas feedback from productivity to pay is supportive of conventional labor demand, feedback from pay to productivity illustrates that pay adjustments influence efficiency.

Consider the following forecasting equations. A forecast of productivity at time $t\left(\operatorname{prd}_{t}\right)$ can be made using past values of productivity $\left(\operatorname{prd}_{t-s}\right)$ and pay $\left(\operatorname{pay}_{t-s}\right)$ :

$$
\operatorname{prd}_{t}=\sum_{s=1} \alpha_{1}(s) p r d_{t-s}+\sum_{s=1} \alpha_{2}(s) p a y_{t-s}+\eta_{1 t},
$$

where the $\alpha^{\prime}$ s are coefficient vectors and $\eta_{1 \mathrm{t}}$ is the random prediction error with variance $v^{2}$.

To identify feedback from pay to productivity, $F_{p a y} \rightarrow p r d$, we must account for the marginal contribution of $p a y_{t-s}$ in the productivity forecast. So we compare the prd $_{t}$ forecast generated with the earnings series to a prediction created without the series. Therefore, we modify equation (1) and estimate $\operatorname{prd}_{t}$ again as follows:

$$
\operatorname{prd}_{t}=\sum_{s=1} \beta_{1}(s) p r d_{t-s}+\eta_{2 t},
$$

\footnotetext{
${ }^{10}$ Since 1966, government members of the Parity Commission have not had voting rights.
} 
where $\operatorname{var}\left(\eta_{2 t}\right)=v_{2}^{2}$. Feedback from pay to productivity is determined by comparing the prediction error variances from equations (1) and (2):

$$
F_{\text {pay } \rightarrow \text { prd }} \equiv \log \left(\mathrm{v}_{2}^{2} / \mathrm{v}^{2}{ }_{1}\right) \text {. }
$$

If the two variances are the same, then pay $_{t-s}$ values do not improve the precision of the

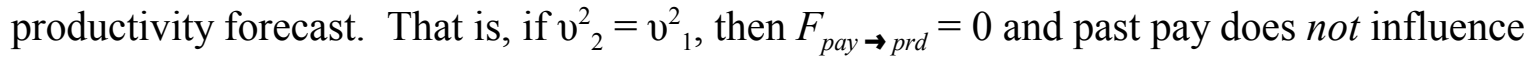
current productivity.

The interrelationship between pay and productivity is likely to differ according to market conditions. The basic feedback method can be extended to include a control variable, which Geweke (1984) called conditioning information. Austrian unemployment has risen steadily since the early 1980 s, from 1.9 percent in 1980 to 7.1 percent in 1997 . In earlier years, specifically 1954-1973, unemployment had fallen from 7.6 percent to 1.2 percent. According to conventional theory, a productivity improvement will induce a pay raise. Presumably, pay will not be as responsive when unemployment has been rising, as it has in recent years. Similarly, any efficiency consequences of pay adjustments are likely to be different when unemployment is climbing. Thus, our feedback measures control for unemployment by including past unemployment rates, $u r_{t-s}$, in the productivity forecasts:

$$
\begin{aligned}
& \operatorname{prd}_{t}=\sum_{s=1} a_{1}(s) p r d_{t-s}+\sum_{s=1} a_{2}(s) p a y_{t-s}+\sum_{s=1} a_{3}(s) u r_{t-s}+\varepsilon_{1 t}, \\
& \operatorname{prd}_{t}=\sum_{s=1} b_{1}(s) p r d_{t-s}+\sum_{s=1} b_{2}(s) u r_{t-s}+\varepsilon_{2 t},
\end{aligned}
$$

where $\operatorname{var}\left(\varepsilon_{i t}\right)=\sigma_{i}^{2}$. Conditional feedback from pay to productivity is simply given by

$$
F_{\text {pay } \rightarrow \text { prd } \mid u r} \equiv \log \left(\sigma_{2}^{2} / \sigma^{2}\right) \text {. }
$$

Controlling for unemployment, if past pay does not influence current productivity, then $F_{\text {pay } \rightarrow \text { prdur }}=0$.

Estimating conditional feedback from productivity to pay follows a similar process. We estimate $\mathrm{pay}_{t}$ as a function of past earnings, productivity, and unemployment:

$$
\text { pay }_{t}=\sum_{s=1} a_{4}(s) \text { pay }_{t-s}+\sum_{s=1} a_{5}(s) p r d_{t-s}+\sum_{s=1} a_{6}(s) u r_{t-s}+\varepsilon_{3 t}
$$

where $\varepsilon_{3 t}$ is the prediction error with variance $\sigma_{3}^{2}$. To isolate the marginal impact of the 
productivity observations, we also estimate pay $_{t}$ without the productivity series:

$$
\operatorname{pay}_{t}=\sum_{s=1} b_{3}(s) \text { pay }_{t-\mathrm{s}}+\sum_{s=1} b_{4}(s) u r_{t-\mathrm{s}}+\mathcal{\varepsilon}_{4 t},
$$

with $\operatorname{var}\left(\mathcal{E}_{4 t}\right)=\sigma_{4}^{2}$. From equations (8) and (7), feedback from productivity to pay is

$$
F_{p r d \rightarrow p a y \mid u r} \equiv \log \left(\sigma_{4}^{2} / \sigma_{3}^{2}\right) \text {. }
$$

Recapping, equations (4-6) illustrate the influence of past pay on the forecast of productivity. Likewise equations (7-9) show the role of past values of productivity on pay.

A distinguishing feature of the Geweke method is that it also accounts for any contemporaneous association between two series, that is, linear association that cannot be disentangled. To identify this simultaneous component, we modify the forecast of $\operatorname{prd}_{t}$ by also including current pay:

$$
\operatorname{prd}_{t}=\sum_{s=1} c_{1}(s) \operatorname{prd}_{t-s}+\sum_{s=0} c_{2}(s) \operatorname{pay}_{t-s}+\sum_{s=1} c_{3}(s) u r_{t-s}+\varepsilon_{5 t}
$$

where $\operatorname{var}\left(\varepsilon_{5 t}\right)=\sigma_{5}^{2}$. Including current earnings may improve the forecast's precision. Thus, the measure of contemporaneous association is defined as

$$
F_{\text {pay }} \cdot \text { prdur } \equiv \log \left(\sigma^{2}{ }_{1} / \sigma^{2}{ }_{5}\right) .
$$

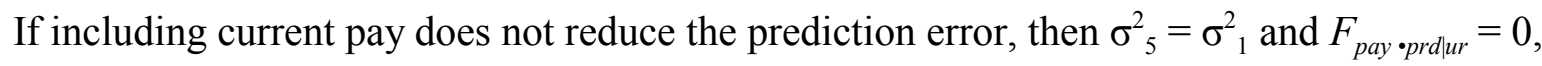
which means there is no contemporaneous association between the series.

Given the different types of feedback, we can now disentangle pay and productivity. The feedback measure $F_{p r d \rightarrow p a y j u r}$ indicates whether productivity leads worker earnings, which would be consistent with conventional labor demand. The measure $F_{p a y} \rightarrow p r d u r$ shows whether pay leads productivity, that is, whether there are efficiency consequences from pay adjustments. Finally, $F_{p a y} \cdot$ prdur shows the extent of simultaneity between pay and $p r d$.

The feedback measures defined above can be transformed using the formula $[1-\exp (-F)]$. For example, transforming $F_{p a y} \rightarrow p r d u r$ shows the proportional reduction in the prediction error variance of $\operatorname{prd}_{t}$ that can be attributed to past values $\operatorname{pay}_{t-s}$, conditional on unemployment. In other words, the transformation illustrates the capacity of past earnings to reduce the variance of prediction error in the productivity forecast. 


\section{Disentangling Pay and Productivity: Geweke Feedback Measures}

Implementing the Geweke Method. The Geweke linear feedback method can be implemented to provide measures of feedback between pay and productivity in Austria. The Austrian Central Statistical Office (ÖSZ) reports only one measure of labor productivity: Real GDP per gainfully employed person, which is available from 1954 through 1997 (for details, see the data appendix).

The ÖSZ reports yearly gross earnings (schillings per month) per employee. So we can assess the interrelationship between employee earnings and labor productivity economy-wide. Unfortunately, the aggregated earnings data do not distinguish between wage earnings of bluecollar workers and salary earnings of white-collar employees. In a statistical compendium documenting the first fifty years of Austria's current republic, 1945-1995, the ÖSZ reported disaggregated figures for wage and salary earnings in the manufacturing sector (see data appendix). For 1954-1995 we can analyze the interrelationship, if any, between manufacturing wages and productivity overall; likewise, we can assess any association between productivity and white-collar salaries in manufacturing.

The productivity and pay series are expressed in real terms. To implement the Geweke method, the forecast equations must be estimated with stationary time series, otherwise estimations may be subject to spurious correlation. We employed the Dickey-Fuller (1981) unit root test for stationarity.

One may wish to use productivity and pay levels to estimate the projection equations. But for the prd and pay series in levels, we cannot reject the null hypothesis of nonstationarity. The first-differences of these series, however, are stationary. Thus in implementing the Geweke method, we used $p r d^{*}{ }_{t} \equiv\left(\operatorname{prd}_{t}-\operatorname{prd}_{t-1}\right)$ and $p a y_{t}{ }_{t} \equiv\left(p a y_{t}-p a y_{t-1}\right)$, which reflect changes in productivity and pay, respectively. ${ }^{11}$

\footnotetext{
${ }^{11}$ Unemployment is not stationary in levels-form but the first-difference is stationary. On the unemployment observations, see the data appendix.
} 
To obtain the $p r d^{*}{ }_{t}$ and pay $^{*}{ }_{t}$ forecasts, we used OLS regression. ${ }^{12}$ Then we computed the conditional feedback measures $F_{p r d^{*} \rightarrow p a y^{*} \mid u r^{*}}, F_{p a y^{*} \rightarrow p r d^{*} \mid u r^{*}}$, and $F_{p a y^{*} \cdot p r d^{*} \mid u r^{*}}$. The feedback estimators are consistent, but because they are based on variances they are nonnegative by construction and potentially biased upward in small samples. Following the method developed by Cushing and McGarvey (1990), we adjusted the point estimates for small sample bias and then created 90-percent confidence bands for each estimator. ${ }^{13}$

Conditional Feedback Results. With earnings, productivity, and unemployment series, we estimated forecasts for $p r d^{*}{ }_{t}$ and $p a y^{*}$. Taking the prediction error variances from these forecasts, we computed conditional feedback point estimates, adjusted each one for small sample bias, and created 90-percent confidence bands. Using $[1-\exp (-F)]$, we transformed the adjusted feedback measures and associated confidence bands, which allows us to gauge the rate of change in the prediction error variance of a forecast.

Table 1 reports conditional feedback measures using employee earnings overall as the pay variable. According to the point estimates, there is not much feedback between $p r d^{*}$ and pay* economy-wide. Past productivity changes barely influence earnings growth. The prediction error variance of $\mathrm{pay}^{*}{ }_{t}$ is reduced by only 1.3 percent when including $\mathrm{prd}_{t-s}{ }^{*}$. Likewise, conditional feedback from $\mathrm{prd}^{*}$ to $\mathrm{pay}^{*}$ is slight, 2.2 percent. Moreover, there is hardly any contemporaneous association (1.2 percent) between earnings and productivity changes.

Although the feedback point estimates are modest, the confidence intervals are very wide (see Table 1), suggesting that any outcome could be possible. Such a finding might not be

\footnotetext{
${ }^{12}$ In the various forecast equations, the optimal lag length was either one (using employee earnings overall as the pay variable) or two (using earnings from the manufacturing sector). Details are available from the authors upon request.

${ }^{13}$ The adjusted feedback point estimates do not have associated test statistics, meaning there is no procedure for direct hypothesis testing. Following the simulation process of Cushing and McGarvey (1990), we can construct bands to indicate the potential magnitude of the feedback measures. For details, see the technical appendix.
} 
surprising considering that the pay variable accounts for both the wages of blue-collar workers and salaries collected by white-collar workers. For the manufacturing sector, it is possible to distinguish between wage $(w g)$ and salary $(s l)$ earnings. Consequently, it may be useful to evaluate Geweke feedback measures using the less aggregated earnings series from manufacturing.

Table 2 presents the conditional feedback measures for manufacturing, with results for wage earners in Panel A and findings for salaried employees in Panel B. In one respect the blueand white-collar findings are similar: There is quite a bit of simultaneity between pay and productivity changes (see third column of Table 2). Nevertheless, there are meaningful differences between wage and salary earners.

Consider the efficiency effects of pay adjustments (second column of table). Focusing on blue-collar workers, changes in wage earnings lead changes in productivity, which is consistent with efficiency wage setting. Past wage adjustments improve the $p r d^{*}$, forecast error variance by 7.3 percent, possibly much more, with the confidence interval reaching 57.0 percent. Efficiency wage contracting cannot be ruled out for Austrian manufacturing, at least for blue-collar workers. Apparently efficiency pay has not extended to white-collar employees, for the conditional feedback point estimate is merely 0.2 (confidence interval only reaches 6.0 ).

Turning to the impact of productivity on pay, so-called conventional labor demand, again there are differences between types of employees (first column of Table 2). Salary earnings are more responsive than wages to productivity. For blue-collar workers, changes in overall productivity do not lead changes in wage earnings. The conditional feedback measure is a scant 0.7 percent. For white-collar employees, in contrast, past productivity changes lead salary adjustments. The feedback point estimate is 4.4 percent, with the confidence interval showing that $p r d_{t-s}^{*}$ improves the $s l_{t}^{*}$ forecast by as much as 29.0 percent.

Our results distinguish between different types of pay practices across different types of workers. Pay adjustments for manufacturing laborers lead changes in productivity; productivity 
changes lead salary adjustments for managers. But strictly speaking, we have not verified that wage increases have had a positive impact on productivity or that productivity gains have led to higher salaries. To confirm the former, we can trace out the reaction of a productivity sequence to a wage stimulus. For the latter, we trace out the reaction of a salary sequence to an innovation in productivity.

\section{Clarifying the Geweke Feedback Measures: Impulse Response Analysis}

The impulse response method developed by Sims (1980) is commonly used to illustrate the response of one time series to an innovation in another series. With the feedback measure $\left.F_{w g^{*} \rightarrow p r d^{*}}\right|_{u r^{*}}$ for wage earners, we implemented the Sims technique to illustrate the response of a productivity series to an innovation in the wage series. A positive $p r d^{*}$ response to a $w g^{*}$ innovation would confirm that a wage hike results in better labor productivity. Measures of the $\operatorname{prd}^{*}$ responses are simply point estimates; we also used the standard errors of the impulse responses to construct a 90-percent significance interval for the estimates.

A graph of the impulse response function and the confidence interval appears in Figure 1, Panel A. Over the sample period, the year-on-year increase in output per employed person averaged approximately 8,500 schillings (measured in 1983 prices). As shown in the graph, there is a strongly positive productivity reaction to a wage innovation. According to the point estimates, the gain in real productivity increases — by nearly 2,000 schillings — immediately following a $w g^{*}$ impulse. Likewise, the lower bound for the significance interval is positive for the first year after the innovation. Such a finding is supportive of efficiency wage contracting: A wage hike for manufacturing laborers does indeed result in a productivity improvement. ${ }^{14}$

\footnotetext{
${ }^{14}$ Instead of efficiency wage behavior, perhaps manufacturing employers reacted to wage growth by implementing new technology or otherwise boosting capital-labor ratios, which might explain labor productivity gains. According to the impulse response function depicted in Panel A of the figure, the labor productivity gain occurs immediately after an innovation in pay, wearing off quickly thereafter. It is unlikely that employers have been able to adjust capital-labor ratios instantly following labor settlements. In heavy manufacturing substantial changes in the quantity
} 
Turning to the feedback measure $\left.F_{p r d^{*} \rightarrow l^{*}}\right|_{u r^{*}}$, we implemented the Sims technique to show how the salary series reacts to a one-standard-deviation innovation in the productivity series. A positive $s l^{*}$ response to a $p r d^{*}$ innovation would confirm that improvement in productivity increases salary gains. A graph of that impulse response function and the confidence interval appears in Panel B of Figure 1.

Better productivity overall leads to a bigger salary hike for manufacturing managers. Over the sample period, the year-on-year increase in salary averaged nearly 500 schillings per month (measured in 1983 prices). According to the impulse point estimates, the salary hike improves by 100 schillings following a prd $^{*}$ impulse, tapering off thereafter. Likewise, the lower bound for the significance interval is positive for the first two periods after the innovation. Salary hikes for manufacturing managers follow improvements in productivity. Whereas wage earners are subject to efficiency wage setting, salaried employees evidently are rewarded according to past performance, which is consistent with conventional labor demand.

\section{Summary of Results and Concluding Remarks}

Conventional theory predicts that productivity gains lead to hikes in real pay. Efficiency wage theory hypothesizes that pay increases can lead to productivity improvements. But would these results be observed in a corporatist economy? It has been alleged that coordinated wage bargaining thwarts the labor market because agreements rely too much on political consensus. But there is a counter that such coordination makes pay claims more moderate and flexible.

For the case of Austria, a corporatist archetype, this study has used an innovative technique developed by Geweke $(1982,1984)$ to examine the interrelationship between earnings and productivity. For the 1954-1995 sample period, we used the Geweke method to disentangle the linear association between manufacturing wage/salary changes and productivity gains, while

or quality of capital can take years to implement and are difficult to reverse. If the capital-labor explanation were to hold, productivity improvement probably would occur after some periods had passed and not decay as quickly. 
controlling for contemporaneous association.

Earlier empirical evidence indicates that pay demands in corporatist economies are relatively modest. Moreover, Teulings and Hartog (1998) hypothesize that corporatist coordination enhances the efficiency of labor contracts, by providing a mechanism to adjust to aggregate shocks. Our findings uncover another efficiency benefit of corporatism.

In an environment in which union wage demands have been restrained, agreement to raise wages may have a propitious effect, improving morale and workers' efforts, thereby benefitting productivity. Indeed, we find that wage increases in manufacturing result in productivity gains. In contrast, managerial salary raises have no impact on productivity. Managers, however, are rewarded following overall improvements in productivity.

The intensity of managerial supervision is greater in Austria than many other European countries (Gordon, 1994). Now we may be able to clarify why this has been case. Boosting the wages of blue-collar workers - who are under fairly close supervision - results in productivity improvements, in turn, yielding salary gains for those supervising managers.

It remains to be seen whether our findings for Austria extend to other corporatist countries. Furthermore, it remains to be seen where, and under what type(s) of supervisory conditions, there may be a similar pay-productivity dichotomy between managers and laborers. As future research concentrates on such issues, we expect the interrelationship between pay and productivity to be clarified further. 


\section{Data Appendix}

Productivity. Real labor productivity is represented by real GDP per gainfully employed person, measured in 1983 schillings per year.

For 1954-1994, real GDP per gainfully employed person is reported in [1, see "Data References" below], Table 15.06, p. 222 (figures in 1976 and 1964 prices converted to 1983 schillings using the 1983 real GDP deflator). For 1995-1997, real productivity growth rates were available in [4], Table 15.07, p. 274; then we calculated productivity figures for 1995-1997.

Earnings. Nominal gross earnings per employee, measured in schillings per month, is reported for 1954-1994 in [1], Table 15.04, p. 220. For 1995-1997, nominal gross earnings growth was available in [4], Table 15.06, p. 273; then we calculated earnings figures for 19951997.

To obtain real gross earnings per employee, we divided nominal earnings by the 1983 GDP deflator. The GDP deflator is simply nominal GDP divided by real GDP.

For 1954-1995, nominal and real GDP (measured in billions of schillings) can be found in [1], Table 15.01, pp. 213-214. For 1995-1997, there are nominal and real GDP growth rates in [4], Tables 15.01 and 15.02, pp. 266-269, which we used to calculate figures for nominal and real GDP, respectively.

Figures for gross nominal monthly earnings (schillings per month) per wage earner, salary earner, and employee (which combines wage and salary earners) in manufacturing for 1954-1993 are reported in [2], Table 4.4, p. 104. Observations for 1994-1995 can be found in [3], Table 9.07, p. 157. To calculate real earnings, we divided nominal earnings by the 1983 GDP deflator.

Unemployment. Unemployment rates for 1954-1993 were provided to the authors, see [5]. Figures for 1984-1997 can be found in [4], Table 7.03, p. 164.

Data References.

1. Österreichisches Statistisches Zentralamt. 1995. Statistisches Jahrbuch für die Republik Österreich 1995. Wien: Österreichisches Statistisches Zentralamt. [Translation: 
Austrian Central Statistical Office. Statistical Yearbook for the Republic of Austria 1995. Vienna: Austrian Central Statistical Office.]

2.___ 1995. Republik Österreich 1945-1995. Wien: Österreichisches Statistisches Zentralamt. [Translation: Republic of Austria 1945-1995. Vienna: Austrian Central Statistical Office.]

3. . 1996. Statistisches Jahrbuch für die Republik Österreich 1996. Wien:

Österreichisches Statistisches Zentralamt. [Translation: Statistical Yearbook for the Republic of Austria 1996. Vienna: Austrian Central Statistical Office.]

4. __ 1999. Statistisches Jahrbuch für die Republik Österreich 1999-2000. Wien: Österreichisches Statistisches Zentralamt. [Translation: Statistical Yearbook for the Republic of Austria 1995. Vienna: Austrian Central Statistical Office.]

5. _ 2000. "Arbeitsmarktlage seit 1946." Table aml_46 of the Bundesministerium für Arbeit und Soziales, Abteilung III/9. Provided to the authors from Claudia Felix of the Österreichisches Statistisches Zentralamt, February 15, 2000. [Translation: "Labor Market Situation since 1946." Table aml_46 of the Federal Ministry for Work and Society, Section III/9.] 


\section{Technical Appendix}

Small Sample Bias Correction and Construction of Confidence Bands. Geweke linear feedback measures are based on prediction error variances, the latter of which are nonnegative. To correct for potential small sample bias, we simulated a sampling distribution for each feedback measure and obtain the mean, the fifth- and ninety-fifth centiles. Following the procedure used by Cushing and McGarvey (1990), we used the mean to adjust each feedback point estimate. To indicate the potential magnitude of the adjusted estimate, we used the upper and lower centiles to create 90-percent confidence bands.

Correcting the conditional feedback measures involves the following steps. Taking equations (4) and (7), we estimated a tri-variate autoregressive (AR) system. With the estimated coefficient matrix that resulted, we simulated observations according to

$$
\tilde{B}(L) W_{t}=e_{t}, \text { where } e_{t} \sim \mathrm{N}(0, \tilde{\Omega})
$$

and $B(L)$ is the estimated coefficient matrix of the tri-variate AR system, $W_{t}$ is the data matrix (containing $p r d^{*}$, $p a y^{*}$, and $u r^{*}$ observations), and $\widetilde{\Omega}$ is the estimated variance of the conditional system. The lag length used in the simulated AR system, equation (A1), is the same as that used to generate the feedback measures. The simulated data are then used to generate feedback measures and the sampling distribution of the feedback point estimates.

There are $\mathrm{k}_{i}$ estimates of type $i$ feedback calculated from the simulations $(i=1,2,3$, where the three types of feedback are $F_{p a y^{*} \rightarrow p r d^{*}}\left|u_{r^{*}}, F_{p r d^{*} \rightarrow p a y^{*}}\right| u r^{*}$, and $\left.F_{p a y^{*} \cdot p r d^{*}} \mid u^{*}\right)$. These sets of $\mathrm{k}_{i}$ estimates provide the sampling distribution of the estimator, $f_{i}$, given the "population," that is, the actual data. Following Cushing and McGarvey, we simulated 200 estimates $\left(\mathrm{k}_{i}=200\right)$ to create sampling distributions for each of the feedback measures.

The simulated mean, $\mathrm{E}\left(f_{i}\right)$, fifth centile, $C_{i 5}$, and ninety-fifth centile, $C_{i 95}$, of the feedback sampling distribution can be used to adjust the feedback measures. Let $l_{i} \equiv C_{i 5} / \mathrm{E}\left(f_{i}\right), u_{i} \equiv$ $C_{i 95} / \mathrm{E}\left(f_{i}\right)$, and $a_{i} \equiv F_{i} / \mathrm{E}\left(f_{i}\right)$, where $F_{i}$ is the unadjusted population feedback measure. With 90- 
percent probability, $f_{i}$ lies between $C_{i 5}$ and $C_{i 95}$ :

$$
\operatorname{Pr}\left\{l_{i} \mathrm{E}\left(f_{i}\right)<f_{i}<u_{i} \mathrm{E}\left(f_{i}\right)\right\}=0.90 .
$$

To adjust the estimates for small sample bias, multiply equation (A2) through by $a_{i}$ :

$$
\operatorname{Pr}\left\{a_{i} l_{i} \mathrm{E}\left(f_{i}\right)<a_{i} f_{i}<a_{i} u_{i} \mathrm{E}\left(f_{i}\right)\right\}=0.90,
$$

where $a_{i} f_{i}$ is the adjusted, unbiased estimator of $F_{i}$. Consequently, we can write

$$
\operatorname{Pr}\left\{l_{\mathrm{i}} F_{i}<a_{j} f_{i}<u_{i} F_{i}\right\}=\operatorname{Pr}\left\{a_{i} f_{i} / u_{i}<F_{i}<a_{i} f_{i} / l_{i}\right\}=0.90 .
$$

Assuming that $a_{\mathrm{i}}, l_{i}$, and $u_{i}$ are averages of the parameters of the sampling distributions of $f_{i}$, the 90 -percent confidence band for $F_{i}$ is

$$
f_{i} a_{\mathrm{i}} / u_{i}<F_{i}<f_{i} a_{\mathrm{i}} / l_{i}
$$

where $f_{i}$ is a feedback point estimate. This procedure ensures that the adjusted point estimate of the feedback, $a_{\mathrm{j}} f_{i}$, always falls within the confidence band.

Applying the adjustment method to the transformed feedback measures, the proportional reduction in forecast error variance for each conditional feedback measure has a 90-percent confidence interval defined as:

$$
\left\{1-\exp \left[-\left(f_{i} a_{\mathrm{i}}\right) / u_{i}\right]\right\}<\left[1-\exp \left(-F_{i}\right)\right]<\left\{1-\exp \left[-\left(f_{i} a_{i}\right) / l_{i}\right]\right\} .
$$




\section{References}

Akerlof, George A. 1982. "Labor Contracts as Partial Gift Exchange." Quarterly Journal of Economics 97 (November): 543-569.

Bean, C. R., P. R. G. Layard, and S. J. Nickell. 1986. "The Rise in Unemployment: A Multicountry Study." Economica 53 (No. 210(S)): S1-S22.

Bruno, Michael and Jeffrey D. Sachs. 1985. Economics of Worldwide Stagflation. Cambridge, MA: Harvard University Press.

Calmfors, Lars and John Driffil. 1988. "Bargaining Structure, Corporatism, and Macroeconomic Performance.” Economic Policy 6 (April): 14-61.

Campbell, Carl M., III. 1993. "Do Firms Pay Efficiency Wages? Evidence with Data at the Firm Level." Journal of Labor Economics 11 (July): 442-470.

Cappelli, Peter and Keith Chauvin. 1991. “An Interplant Test of the Efficiency Wage Hypothesis." Quarterly Journal of Economics 106 (August): 769-787.

Carmichael, H. Lorne. 1990. "Efficiency Wage Models of Unemployment - One View." Economic Inquiry 28 (April): 269-295.

Cushing, Matthew J. and Mary G. McGarvey. 1990. "Feedback between Wholesale and Consumer Price Inflation: A Reexamination of the Evidence." Southern Economic Journal 56 (April): 1059-1072.

Dickey, D. A. and W. A. Fuller. 1981. "Likelihood Ratio Statistics for Autoregressive Time Series with a Unit Root.” Econometrica 49 (June): 1057-1072.

Flanagan, Robert J., David W. Soskice, and Lloyd Ulman. 1983. Unionism, Economic Stabilization, and Incomes Policies: European Experience. Washington, DC: The Brookings Institution.

Geweke, John. 1982. "Measurement of Linear Dependence and Feedback between Multiple Time Series." Journal of the American Statistical Association 77 (June): 304-313. 
. 1984. "Measurement of Conditional Linear Dependence and Feedback between Time Series." Journal of the American Statistical Association 79 (December): 907-915.

Gordon, David M. 1994. "Bosses of Different Stripes: A Cross-National Perspective on Monitoring and Supervision.” American Economic Review 84 (May): 375-379.

Granger, C. W. J. 1969. "Investigating Causal Relationships by Econometric Models and CrossSpectral Methods." Econometrica 37 (August): 424-438.

Karlhofer, Ferdinand and Ulrich Ladurner. 1993. “The Austrian Labour Market: Description and Analysis of Structures and Institutions," in Labour Market Contracts and Institutions: A Cross-National Comparison, (eds.) Joop Hartog and Jules Theeuwes. Amsterdam: North-Holland, pp. 185-207.

Katzenstein, Peter J. 1984. Corporatism and Change: Austria, Switzerland, and the Politics of Industry. Ithaca, NY: Cornell University Press.

Kindley, Randall W. 1992. "From Class Conflict to Class Cooperation: The Evolution of Austrian Cooperation.” Working Paper 92-2 (February), Center for Austrian Studies, University of Minnesota.

Millea, Meghan. 1998. “A Direct Test of Efficiency Wage Theory: Evidence from the U.S. and Other OECD Countries.” Ph.D. dissertation, University of Nebraska.

Nowotny, Ewald. 1993. "The Austrian Social Partnership and Democracy." Working Paper 93-1 (February), Center for Austrian Studies, University of Minnesota.

Olson, Mancur. 1982. The Rise and Decline of Nations. Economic Growth, Stagflation, and Social Rigidities. New Haven: Yale University Press.

Pichelmann, Karl and Michael Wagner. 1986. "Labour Surplus as a Signal for Real-Wage Adjustment." Economica 53 (No. 210(S)): S75-S87.

Salop, Steven C. 1979. "A Model of the Natural Rate of Unemployment." American Economic Review 69 (March): 117-125. 
Shapiro, Carl and Joseph E. Stiglitz. 1984. "Equilibrium Unemployment as a Worker Discipline Device." American Economic Review 74 (June): 433-444.

Sims, C. A. 1980. “Macroeconomics and Reality.” Econometrica 48 (January): 1-48.

Tarantelli, Ezio. 1986. “The Regulation of Inflation and Unemployment.” Industrial Relations 25 (Winter): 1-15.

Teulings, Coen and Joop Hartog. 1998. Corporatism or Competition? Cambridge, U.K.: Cambridge University Press. 


\section{Table 1}

Disentangling Employee Earnings and Productivity, 1954-1997:

Geweke Conditional Linear Feedback Measures ${ }^{a}$

Percent Reduction in the Prediction Error Variance of

Employee Earnings and Productivity Forecasts:

Adjusted Point Estimates (90-Percent Confidence Bands)

Employees overall

Feedback Measures $^{b}$
$F_{p r d^{*} \rightarrow \text { pay* }} \mid u r^{*}$
$F_{\text {pay* } \rightarrow p r d *} \mid u r^{*}$
$F_{\text {pay* }} \cdot$ prd $^{*} \mid u r^{*}$
1.28
2.22
1.22
$(0.35,93.51)$
$(0.71,89.03)$
$(0.32,96.68)$

${ }^{\mathrm{a}}$ For the earnings, productivity, and unemployment data, see the data appendix.

${ }^{\mathrm{b}}$ Conditional feedback from productivity to employee earnings, $F_{p r d^{*} \rightarrow p a y^{*}} \mid u r^{*}$, see equations (7-9).

Conditional feedback from employee earnings to productivity, $F_{p a y^{*} \rightarrow p r d^{*} \mid u r^{*}}$, see equations (4-6).

Conditional contemporaneous association between employee earnings and productivity,

$F_{p a y^{*} \cdot p r d^{*} \mid u r^{*}}$, see equations $(4,10-11)$. In all cases, $\operatorname{pay}_{t}{ }_{t} \equiv\left(p a y_{t}-\operatorname{pay}_{t-1}\right) ; p r d^{*}{ }_{t} \equiv\left(\operatorname{prd}_{t}-\operatorname{prd}_{t-1}\right)$; $u r_{t}^{*} \equiv\left(u r_{t}-u r_{t-1}\right)$. 


\section{Table 2}

Disentangling Manufacturing Salary/Wage Earnings and Productivity, 1954-1995:

Geweke Conditional Linear Feedback Measures ${ }^{a}$

Percent Reduction in the Prediction Error Variance of

Salary /Wage and Productivity Forecasts:

Adjusted Point Estimates (90-Percent Confidence Bands)

Panel A: Wage earners

Feedback Measures ${ }^{\mathrm{b}}$
$F_{p r d^{*} \rightarrow w g^{*}} \mid u r^{*}$
$F_{w g^{*} \rightarrow p r d^{*}} \mid u r^{*}$
$F_{w g^{*} \cdot p r d^{*} \mid u r^{*}}$
0.67
$(0.26,13.93)$
7.26
$(2.79,56.98)$
20.89
$(8.27,99.84)$

Panel B: Salary earners

Feedback Measures ${ }^{\mathrm{c}}$

$\begin{array}{ccc}F_{p r d^{*} \rightarrow s l^{*} \mid u r^{*}} & F_{s l^{*} \rightarrow p r d^{*} \mid u r^{*}} & F_{s l^{*} \cdot p r d^{*} \mid u r^{*}} \\ 4.37 & 0.23 & 24.32 \\ (2.08,29.04) & (0.07,5.98) & (9.78,99.91)\end{array}$

${ }^{\mathrm{a}}$ For the salary, wage, productivity, and unemployment data, see the data appendix.

${ }^{\mathrm{b}}$ Conditional feedback from productivity to wage earnings, $F_{p r d^{*} \rightarrow w g^{*}} \mid u r^{*}$, see equations (7-9).

Conditional feedback from wage earnings to productivity, $F_{w g^{*} \rightarrow p r d^{*} \mid u r^{*}}$, see equations (4-6).

Conditional contemporaneous association between wage earnings and productivity, $F_{w g^{*} \cdot p^{*} \mid u r^{*} \text {, }}$ see equations $(4,10-11)$. In all cases, $w g_{t}^{*} \equiv\left(w g_{t}-w g_{t-1}\right) ; p r d^{*}{ }_{t} \equiv\left(p r d_{t}-p r d_{t-1}\right) ; u r_{t}^{*} \equiv\left(u r_{t}-u r_{t-1}\right)$.

${ }^{\mathrm{c}}$ Conditional feedback from productivity to salary earnings, $F_{p r d^{*} \rightarrow s^{*} \mid u r^{*}}$, see equations (7-9).

Conditional feedback from salary earnings to productivity, $F_{s l^{*} \rightarrow p r d^{*} \mid u r^{*}}$, see equations (4-6).

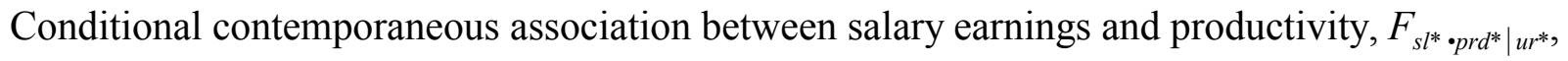
see equations $(4,10-11)$. In all cases, $s l_{t}^{*} \equiv\left(s l_{t}-s l_{t-1}\right) ; p r d^{*}{ }_{t} \equiv\left(p r d_{t}-p r d_{t-1}\right) ; u r^{*}{ }_{t} \equiv\left(u r_{t}-u r_{t-1}\right)$. 
Figure 1:

Impulse Response Functions

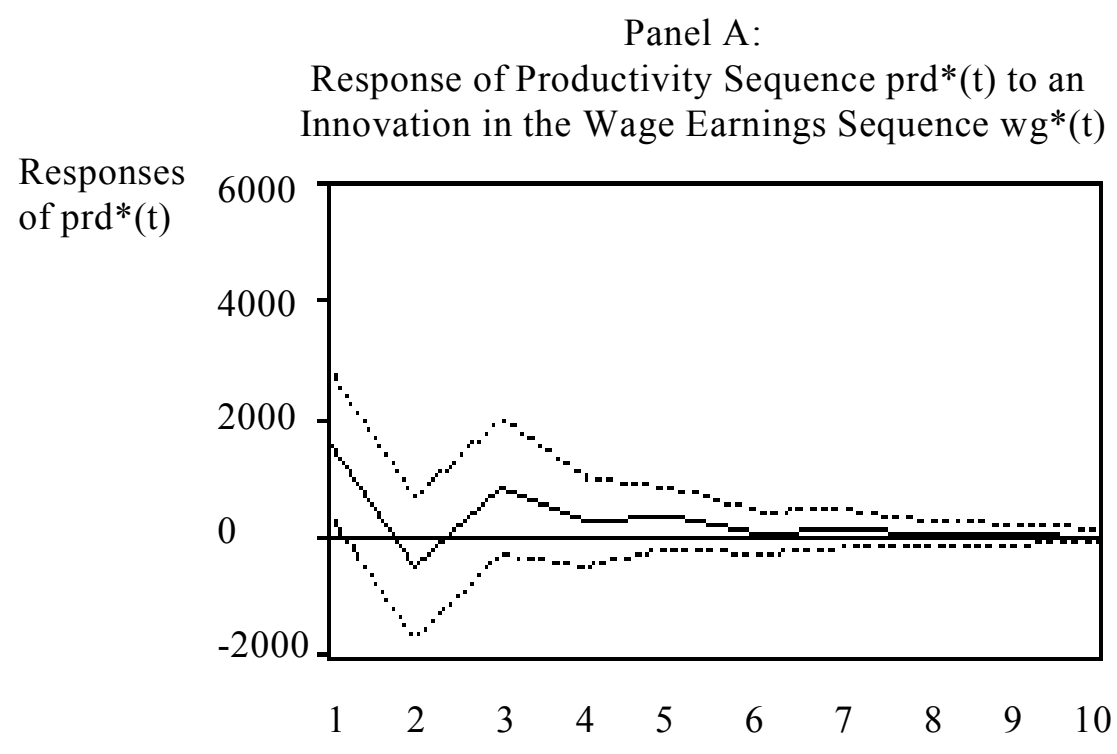

Panel B:

Response of Salary Earnings $\mathrm{s}^{*}(\mathrm{t})$ to an Innovation in the Productivity Sequence $\operatorname{prd}^{*}(\mathrm{t})$

Responses of $\mathrm{sl}^{*}(\mathrm{t})$

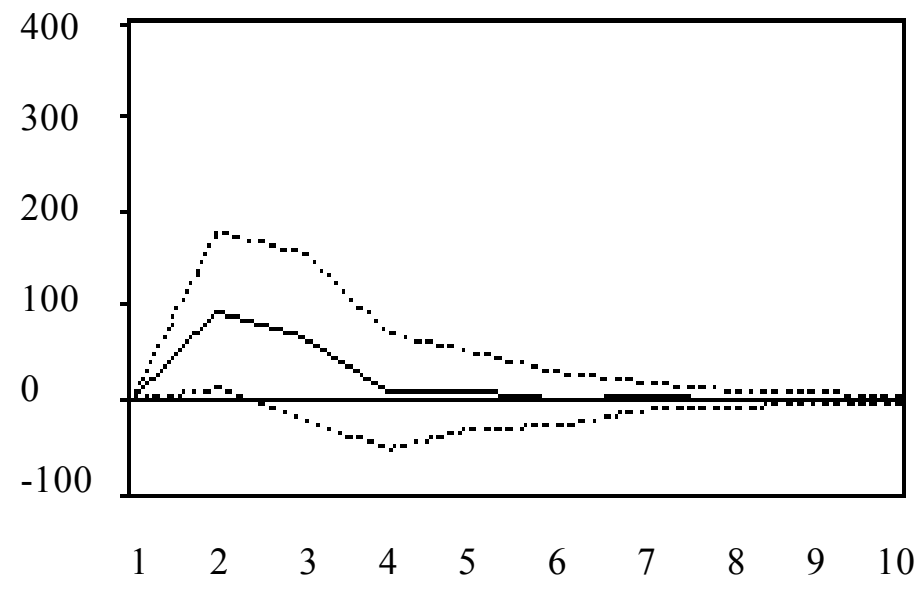

Legend Impulse Response Point Estimates

- - - - 90 Percent Confidence Bands 


\section{IZA Discussion Papers}

No Author(s)

161

V. Gimpelson

D. Treisman

G. Monusova

162

C. Dustmann

M. E. Rochina-

Barrachina

R. A. Hart

Y. Ma

164 M. A. Shields

S. Wheatley Price

165

A. Barrett

J. FitzGerald

B. Nolan

G. S. Epstein

A. L. Hillman

R. Winkelmann

T. K. Bauer

K. F. Zimmermann

C. Dustmann

F. Windmeijer

D. Card

D. S. Hamermesh

E. Fehr

J.-R. Tyran

M. Lofstrom

W. Meyer

Titel

Area

Date

Public Employment and Redistributive Politics:

4

$6 / 00$

Evidence from Russia's Regions

Selection Correction in Panel Data Models: An 6

Application to Labour Supply and Wages

Why do Firms Pay an Overtime Premium?

5

$6 / 00$

Racial Harassment, Job Satisfaction and Intentions

5

$6 / 00$

to Quit: Evidence from the British Nursing Profession

Immigration in a High Unemployment Economy: 1

$6 / 00$ The Recent Danish Experience

The Impact of Alcohol Consumption on Occupa- 5 tional Attainment in England

$6 / 00$

Earnings Inequality, Returns to Education and 5 Immigration into Ireland

$6 / 00$

Social Harmony at the Boundaries of the Welfare 3 State: Immigrants and Social Transfers

$6 / 00$

Immigration Policies and their Impact: The Case of 1

$7 / 00$

New Zealand and Australia

Immigration Policy in Integrated National

$7 / 00$

Economies

Wages and the Demand for Health - A Life Cycle 5

$7 / 00$

Analysis

Reforming the Financial Incentives of the Welfare 3

System

$7 / 00$

Timing, Togetherness and Time Windfalls

$7 / 00$

Does Money Illusion Matter? An Experimental

7

$7 / 00$

Approach

Self-Employment and Earnings among High-

Skilled Immigrants in the United States

Industrial Relations and the Wage Differentials

5

$7 / 00$ between Skilled and Unskilled Blue-Collar

Workers within Establishments: An Empirical

Analysis with Data of Manufacturing Firms 
177 B. R. Chiswick

G. Repetto

178 R. Euwals M. Ward

179 E. Wasmer

P. Weil

180 T. K. Bauer

I. N. Gang

181 E. Wasmer

Y. Zenou

182 M. Fertig

C. M. Schmidt

183 M. Fertig

C. M. Schmidt

184 M. Corak

B. Gustafsson

T. Österberg

185

H. Bonin

K. F. Zimmermann

186

C. Dustmann

T. K. Bauer

M. Lofstrom

K. F. Zimmermann

188 A. Kapteyn

A. S. Kalwij

A. Zaidi

189 W. Arulampalam

190

C. Dustmann

I. Preston

191

G. C. Giannelli

C. Monfardini

192

G. Brunello

A. Kunze
Immigrant Adjustment in Israel: Literacy and

Fluency in Hebrew and Earnings

The Renumeration of British Academics

The Macroeconomics of Labor and Credit Market Imperfections

Sibling Rivalry in Educational Attainment:

The German Case

Space, Search and Efficiency

2

Discretionary Measures of Active Labor Market

Policy: The German Employment Promotion Reform in Perspective

Aggregate-Level Migration Studies as a Tool for 1 Forecasting Future Migration Streams

Intergenerational Influences on the Receipt of

3

Unemployment Insurance in Canada and Sweden

The Post-Unification German Labor Market

4

$8 / 00$

Temporary Migration and Economic Assimilation

$8 / 00$

Immigration Policy, Assimilation of Immigrants and Natives' Sentiments towards Immigrants: Evidence from 12 OECD-Countries

The Myth of Worksharing

Is Unemployment Really Scarring? Effects of Unemployment Experiences on Wages

Racial and Economic Factors in Attitudes to Immigration

Joint Decisions on Household Membership and Human Capital Accumulation of Youths: The role of expected earnings and local markets

Absolute Risk Aversion and the Returns to Education

The Determination of Wages and the Gender Wage Gap: A Survey 
195 F. Büchel

A. Mertens

196 J. S. Earle

K. Z. Sabirianova

197

G. A. Pfann

198 M. Kreyenfeld

C. K. Spiess

G. G. Wagner

199 H. Entorf

200 T. Bauer

G. S. Epstein

I. N. Gang

201 T. J. Dohmen

G. A. Pfann

202

P. Francois

J. C. van Ours

203
J. M. Abowd
F. Kramarz
D. N. Margolis
T. Philippon

204

G. S. Epstein
A. L. Booth
M. Francesconi
J. Frank

206 C. M. Schmidt

R. Baltussen

R. Sauerborn

C. M. Schmidt

J. Hartog

R. Winkelmann

209 M. Barbie

M. Hagedorn

A. Kaul

210 T. J. Dohmen
Overeducation, Undereducation, and the Theory

of Career Mobility

Equilibrium Wage Arrears: A Theoretical and 4

Empirical Analysis of Institutional Lock-In

Options to Quit

1

$9 / 00$

A Forgotten Issue: Distributional Effects of Day 3

Care Subsidies in Germany

Rational Migration Policy Should Tolerate Non-

Zero Illegal Migration Flows: Lessons from

Modelling the Market for Illegal Migration

What are Migration Networks?

$9 / 00$

Worker Separations in a Nonstationary Corporate 1 Environment

Gender Wage Differentials in a Competitive Labor Market: The Household Interaction Effect

The Tail of Two Countries: Minimum Wages and 5 Employment in France and the United States

5

$9 / 00$

$9 / 00$

Labor Market Interactions Between Legal and

1

$10 / 00$ Illegal Immigrants

Temporary Jobs: Stepping Stones or Dead Ends? 1

$10 / 00$

The Evaluation of Community-Based Interventions: Group-Randomization, Limits and Alternatives

Arbeitsmarktpolitische Maßnahmen und ihre

6

$10 / 00$

Evaluierung: eine Bestandsaufnahme

Dutch Migrants in New Zealand:

Did they Fare Well?

1

$10 / 00$

Dynamic Effciency and Pareto Optimality in a

3

$10 / 00$ Stochastic OLG Model with Production and Social Security 

211 A. van Soest
M. Das
X. Gong
212 X. Gong
A. van Soest
P. Zhang
213 X. Gong
A. van Soest
E. Villagomez

214 X. Gong

A. van Soest

215 J. Ermisch

M. Francesconi

216 F. Büchel

217 J. Hansen

R. Wahlberg

218 C. Dustmann

A. van Soest

219 F. Kramarz

T. Philippon

220 W. A. Cornelius

E. A. Marcelli

221

C. Grund

222 W.P.M. Vijverberg

223 M. Rosholm

M. Svarer

224

J. Schwarze

225

L. Modesto

J. P. Thomas
A Structural Labour Supply Model with

The Effects of Overeducation on Productivity in Mexico

Wages as Risk Compensation in Germany 

former Soviet Union to Israel: Who is coming when? 
242 G. Faggio

Job Creation, Job Destruction and Employment

4 the 1990s

244 S. M. Fuess, Jr.

Pay and Productivity in a Corporatist Economy:

5 M. Millea 